\title{
Article
}

\section{The Effect of Ball Burnishing on Dry Fretting}

\author{
Slawomir Swirad (1) and Pawel Pawlus *
}

Faculty of Mechanical Engineering and Aeronautics, Rzeszow University of Technology,

Powstancow Warszawy 8 Street, 35-959 Rzeszow, Poland; s.swirad@prz.edu.pl

* Correspondence: ppawlus@prz.edu.pl; Tel.: +48-17-865-1904

\section{check for} updates

Citation: Swirad, S.; Pawlus, P. The Effect of Ball Burnishing on Dry Fretting. Materials 2021, 14, 7073.

https://doi.org/10.3390/ma14227073

Academic Editor: Itzhak Green

Received: 18 October 2021

Accepted: 18 November 2021

Published: 21 November 2021

Publisher's Note: MDPI stays neutral with regard to jurisdictional claims in published maps and institutional affiliations.

Copyright: (c) 2021 by the authors. Licensee MDPI, Basel, Switzerland. This article is an open access article distributed under the terms and conditions of the Creative Commons Attribution (CC BY) license (https:/ / creativecommons.org/licenses/by/ $4.0 /)$.

\begin{abstract}
Experiments were conducted under a dry gross fretting regime. Steel discs were put in contact with ceramic balls. Before tribological tests, discs were subjected to ball burnishing with different pressures. Due to ball burnishing, a decrease in surface amplitude and an increase in microhardness occurred. Ball burnishing caused decreases in the friction force and volumetric wear of up to $45 \%$ in comparison to sliding pairs containing milled discs. The friction force and volumetric wear were higher for a higher roughness of disc.
\end{abstract}

Keywords: ball burnishing; surface topography; friction; wear

\section{Introduction}

The aim of ball burnishing is to improve the functional properties of the surface. During ball burnishing, the ball pressed to the machined surface moves along the assumed path. Plastic deformation occurs, without material removal. This treatment leads to a decrease in hardness, an improvement of residual stresses, and a decrease in roughness height. There are many parameters that affect surface quality after ball burnishing. Among them, burnishing speed, feed, and force are the most important [1]. Saldaña-Robles et al. [2] changed these three parameters, Jerez-Mesa et al. [3] studied the effect of burnishing speed and feed, El-Tayeb et al. [4] changed burnishing speed and force, Rodriguez [5] and Swirad and Pawlus [6] changed burnishing force. Too high a burnishing force can lead to surface deterioration. However, Rodriguez et al. [5] found that high burnishing force caused the increase in hardness even in cases of surface destruction. Typically, studies of the effects of burnishing parameters on surface roughness and hardness were performed [7,8]. Researchers tried to predict analytically the roughness of the burnished surfaces $[9,10]$.

As the burnishing process can improve the surface quality, the effects of burnished surfaces on the improvement of functional properties were studied. These improvements are mostly connected with a hardness increase and a decrease in roughness height. Revankar et al. [11] achieved a reduction in wear and friction of more than two times due to ball burnishing of titanium alloy. Travieso-Rodriguez et al. [12] increased the fatigue lifespan of AISI 1038 specimens by up to 77\% during the application of ball burnishing. Similar effects were achieved as the result of shot peening. Hardness growth caused considerable wear reduction $[13,14]$. El-Tayeb [4] found that burnishing led to friction reduction in comparison to the behavior of turned surfaces. Swirad and Pawlus found that ball burnishing caused reductions in wear and friction under dry sliding compared to milled samples [6]. Ball burnishing led to a decrease in the coefficient of friction in lubricated sliding [15], this effect was related to the improvement of surface quality of steel samples.

Fretting is a relative motion of low amplitude. It occurs when the sliding amplitude is smaller than the radius of the elastic contact [16]. For higher amplitude, reciprocating sliding happens. Fretting can be divided into partial slip and gross slip [17-19]. These regimes can be identified based on the slip index calculated on the basis of fretting loops $[20,21]$. Partial slip leads to fretting fatigue (cracks), while the gross slip leads to wear, typically abrasive and adhesive [22]. Fretting wear is related to created oxide debris, this effect can be 
positive or negative $[22,23]$. A decrease in the normal load caused a decrease in volumetric wear. For high contact pressure, partial slip is possible [24]. The effect of hardness on fretting wear is not clear. Oxide debris can be embedded in the softer surface, causing increased wear of a harder sample [25]. Budinski [26] found that wear increased when the difference between the hardness of two counterparts increased. Researchers obtained various effects of surface topography on fretting. An opinion exists that rougher surface debris can be accumulated in the valleys, reducing wear [27]. However, the obtained effects of surface roughness on fretting wear and friction were sometimes contradictory. Kubiak et al. [28,29] achieved a smaller coefficient of friction for rougher samples. Lenart et al. obtained various results depending on the hardness of two counterparts. For similar hardness of two steel samples, the wear volume of the tribological system was larger for higher disc roughness [30]. When a harder ball co-acted with a softer disc, the roughness height of the disc had a negligible influence on tribological properties [31]. When a steel disc contacted a ceramic ball, the smoother discs produced smaller friction and wear than the rougher discs [32]. Lu et al. [33] found that in torsional fretting wear levels were lower when the one-directional texture was perpendicular to the movement direction.

It is difficult to find in technical literature dependencies between parameters of ball burnishing and friction and wear under dry fretting. The authors of this paper try to fill this gap.

The purpose of this work is to study the effect of ball burnishing process on dry gross fretting.

\section{Materials and Methods}

Fretting tests were carried out in ball-on-disc configuration. Ceramic ball made of WC material of $10 \mathrm{~mm}$ diameter contacted steel disc made of $42 \mathrm{CrMo}_{4}$ material of $42 \pm 2 \mathrm{HRC}$ hardness. The experiments were carried out at $30^{\circ} \mathrm{C}$ temperature, the relative humidity was $35-45 \%$, the frequency was $50 \mathrm{~Hz}$, the stroke was $0.1 \mathrm{~mm}$, and the number of cycles was 45,000 . The normal load changed, it obtained values of 20,30, 40, and $50 \mathrm{~N}$. For all normal loads, the elastic contact diameter was higher than the stroke. The discs had a diameter of $25.4 \mathrm{~mm}$ and a height of $9 \mathrm{~mm}$. They were subjected to ball burnishing using the Haas CNC Vertical Mill Center VF-1 equipped with Ecoroll burnishing system (HG-6). The burnishing tool had a $6 \mathrm{~mm}$ diameter. Spiral burnishing strategy was chosen, burnishing speed was $500 \mathrm{~mm} / \mathrm{min}$, and burnishing width was $0.01 \mathrm{~mm}$. Burnishing speed was constant during machining. The burnishing width is defined as the distance between the two next paths of the burnishing tool and was constant during machining to obtain similar surface characteristics.

There were the following burnishing pressures: 10, 20, 30, and $40 \mathrm{MPa}$. The number of test repetitions was three. During the test, the coefficient of friction was monitored.

The disc samples were milled prior to burnishing. Before tests, the measurements of disc surfaces were carried out using Talysurf CCI Lite white light interferometer (Taylor Hobson Ltd., Leicester, UK) of $0.01 \mathrm{~nm}$ vertical resolution. The measuring sample of $3.3 \mathrm{~mm} \times 3.3 \mathrm{~mm}$ area contained $1024 \times 1024$ data points. Before the calculations of the texture parameters using TalyMap software (Gold 6.0), each surface was leveled without using digital filtration. Spikes were eliminated. Surface textures of worn samples were also studied using Phenom ProX desktop SEM (Thermo Fisher, Waltham, MA, USA).

Surface microhardness was measured using tester Reicherter Brivisor KL2 Vickers microindenters (Buehler Ltd., Lake Bluff, IL, USA) with a lens system. Tests were conducted by applying a $3 \mathrm{~N}$ load with a load duration of $20 \mathrm{~s}$.

To obtain wear volumes, balls and discs were measured after tests. The volumetric wear of the tribological system was the sum of the wear volumes of the disc and ball [34].

Figure 1 presents a scheme of the experimental arrangement. 

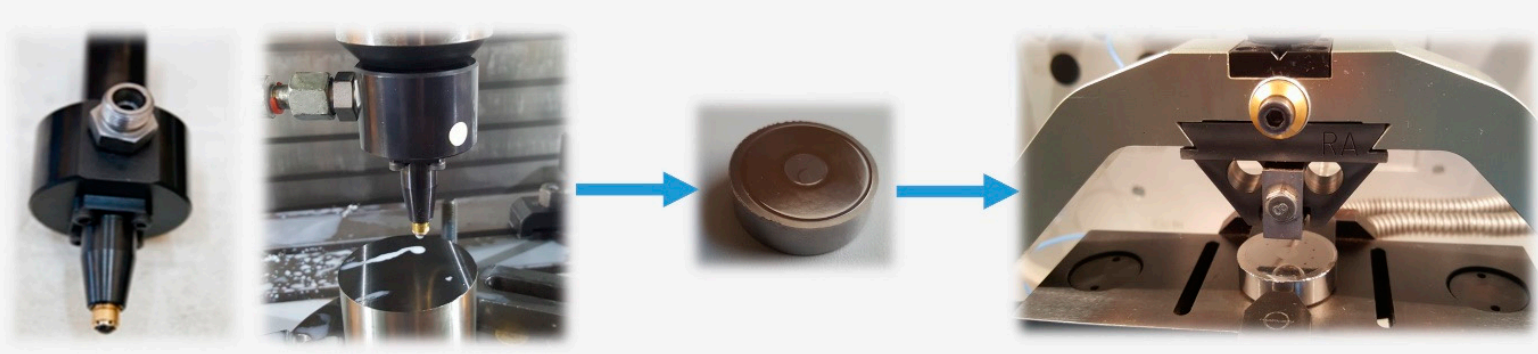

Hydrostatic burnishing equipment
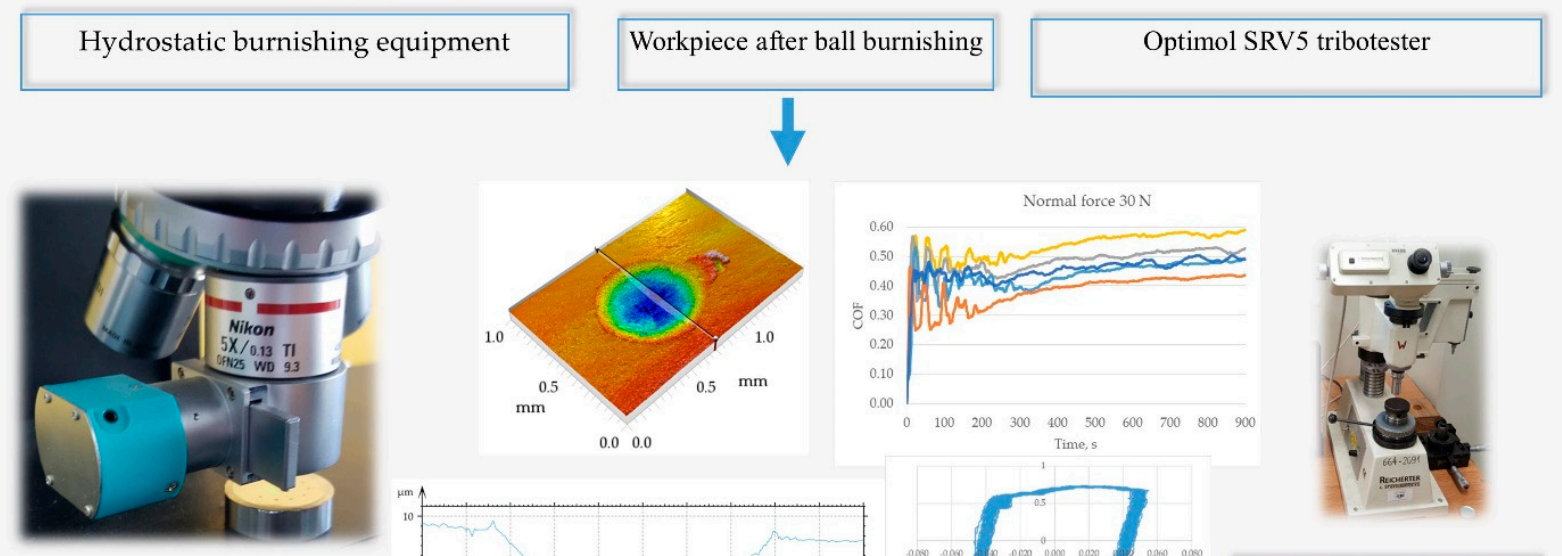

Non-contact 3D surface measurement
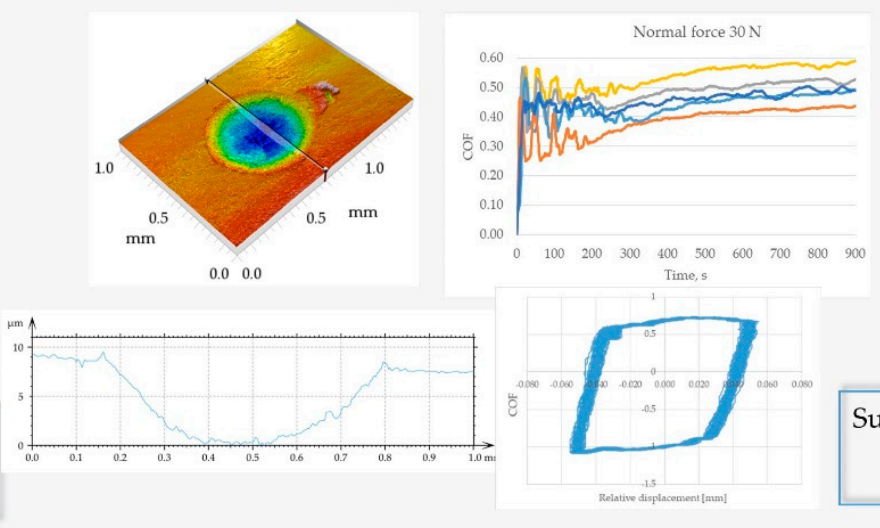

Surface microhardness measurement

Figure 1. A scheme of the experimental arrangement.

\section{Results}

Figure 2 presents isometric views and contour plots of machined samples.

Figure 3 shows roughness profiles of tested disc surfaces before tests.

Table 1 lists the parameters of the disc samples according to the ISO 25172-2 standard. Reference [35] presents the definitions of these parameters.

Table 1. Selected areal parameters of disc surfaces.

\begin{tabular}{|c|c|c|c|c|c|}
\hline \multirow{2}{*}{$\begin{array}{c}\text { Disc } \\
\text { Parameters }\end{array}$} & \multirow{2}{*}{$\frac{\text { Milled }}{-}$} & \multicolumn{4}{|c|}{ Burnished } \\
\hline & & $10 \mathrm{MPa}$ & $20 \mathrm{MPa}$ & $30 \mathrm{MPa}$ & $40 \mathrm{MPa}$ \\
\hline $\mathrm{Sq}, \mu \mathrm{m}$ & 0.577 & 0.135 & 0.138 & 0.110 & 0.269 \\
\hline Ssk & 0.312 & 0.090 & 0.164 & -0.184 & 0.060 \\
\hline Sku & 2.195 & 3.527 & 3.094 & 3.168 & 4.121 \\
\hline $\mathrm{Sp}, \mu \mathrm{m}$ & 1.892 & 0.986 & 0.696 & 0.479 & 0.935 \\
\hline $\mathrm{Sv}, \mu \mathrm{m}$ & 2.648 & 0.806 & 0.549 & 0.550 & 1.080 \\
\hline $\mathrm{Sz}, \mu \mathrm{m}$ & 4.539 & 1.792 & 1.245 & 1.029 & 2.015 \\
\hline $\mathrm{Sa}, \mu \mathrm{m}$ & 0.482 & 0.106 & 0.110 & 0.087 & 0.202 \\
\hline Sal, mm & 0.024 & 0.199 & 0.051 & 0.105 & 0.151 \\
\hline Str & 0.014 & 0.683 & 0.341 & 0.665 & 0.452 \\
\hline Sdq & 0.075 & 0.013 & 0.013 & 0.012 & 0.023 \\
\hline
\end{tabular}



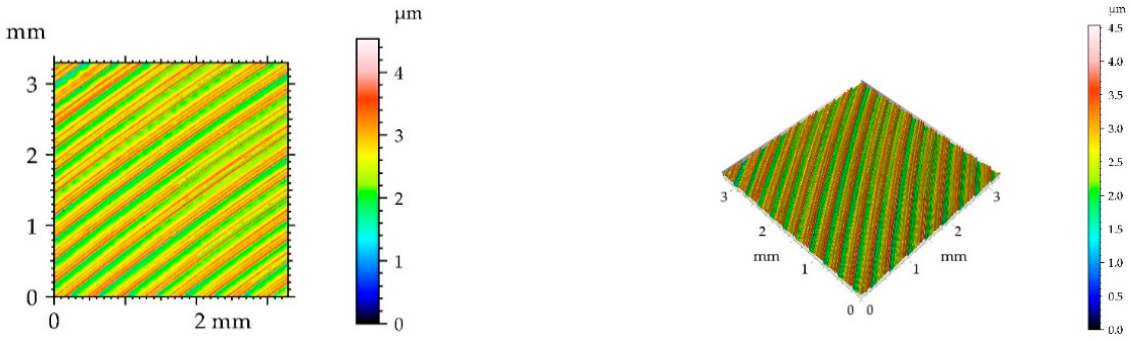

(a)
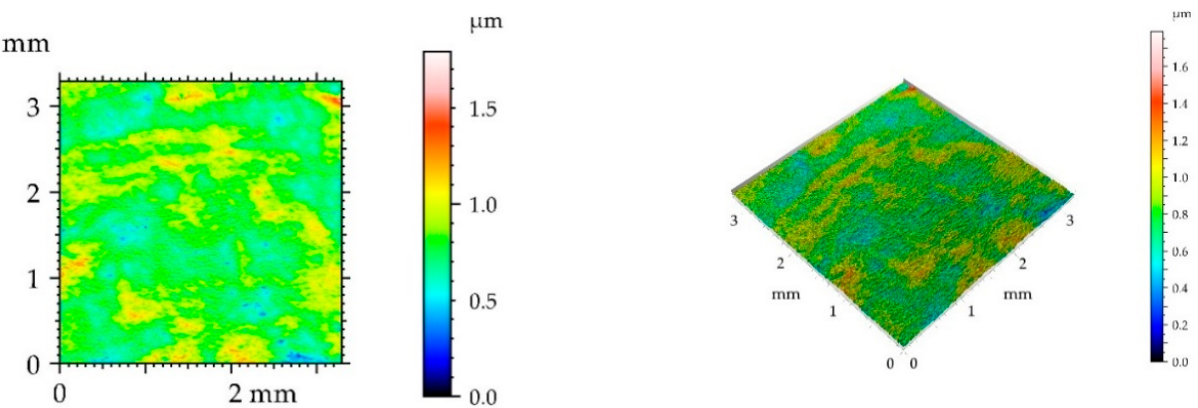

(b)
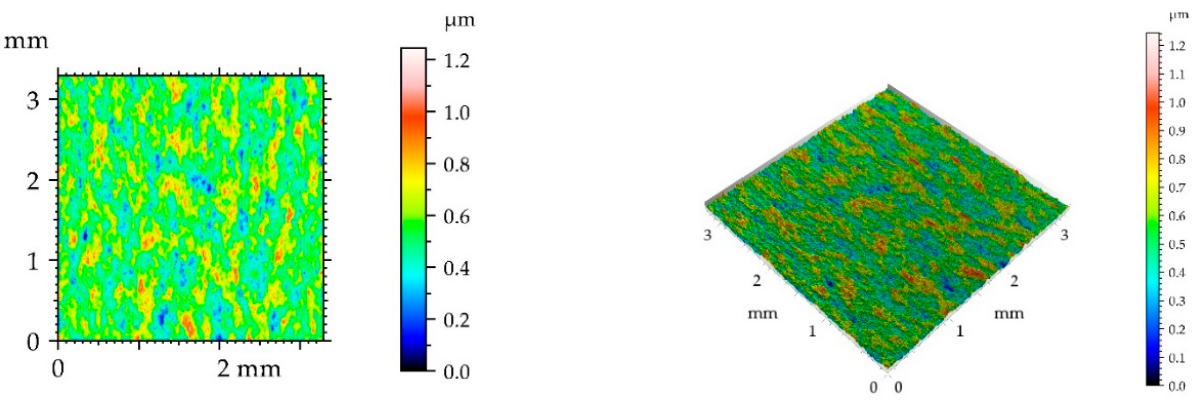

(c)
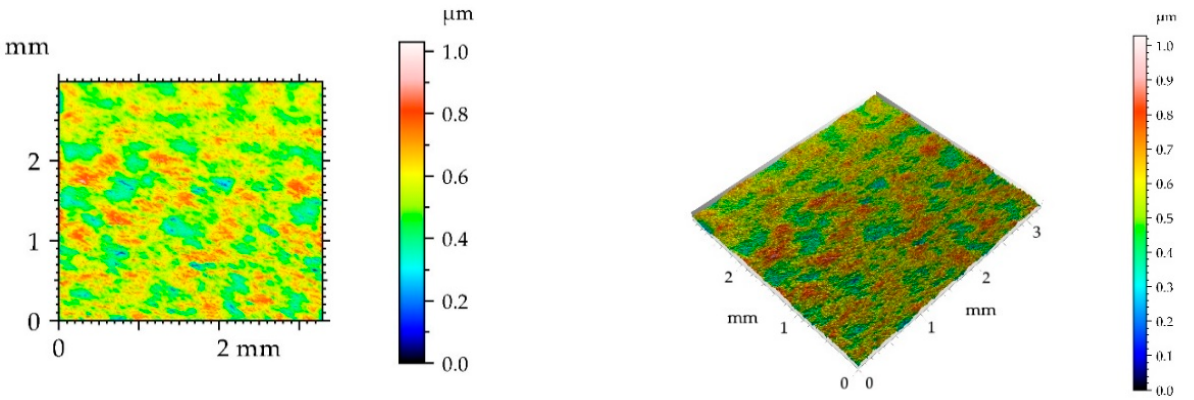

(d)
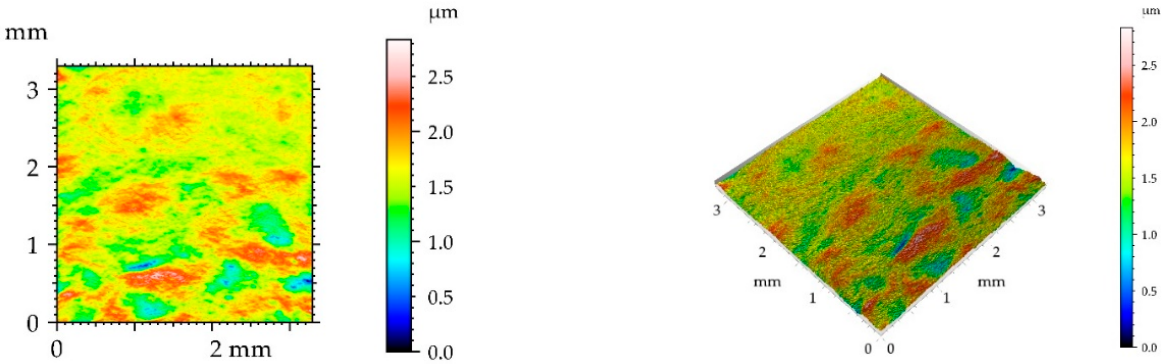

(e)

Figure 2. Contour plots (left) and isometric views (right) of milled disc surface (a), and of burnished disc surfaces with pressures of 10 (b), 20 (c), 30 (d), and $40 \mathrm{MPa}(\mathbf{e})$. 


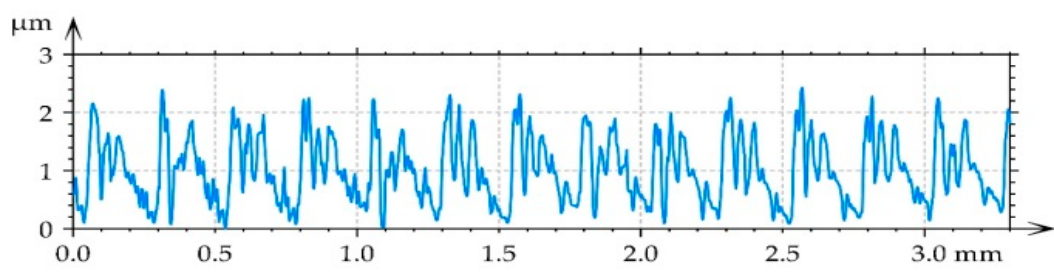

(a)

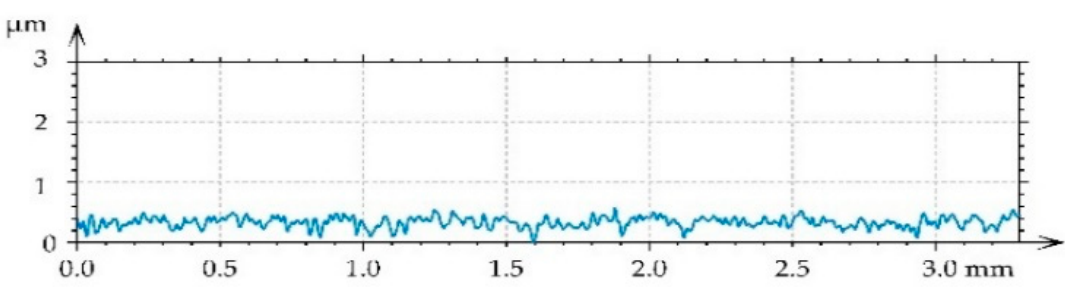

(b)

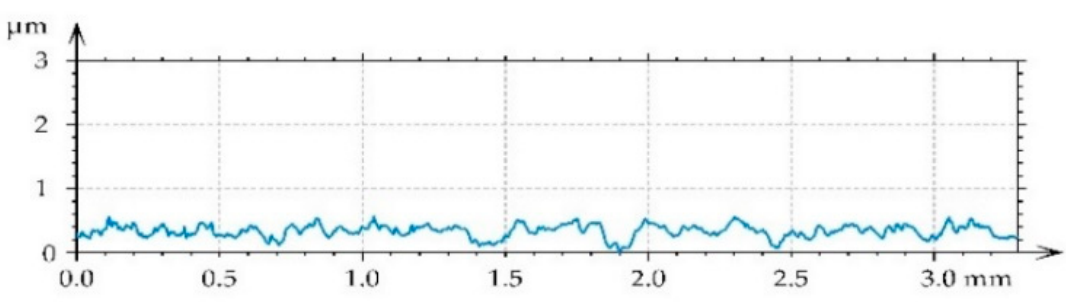

(c)

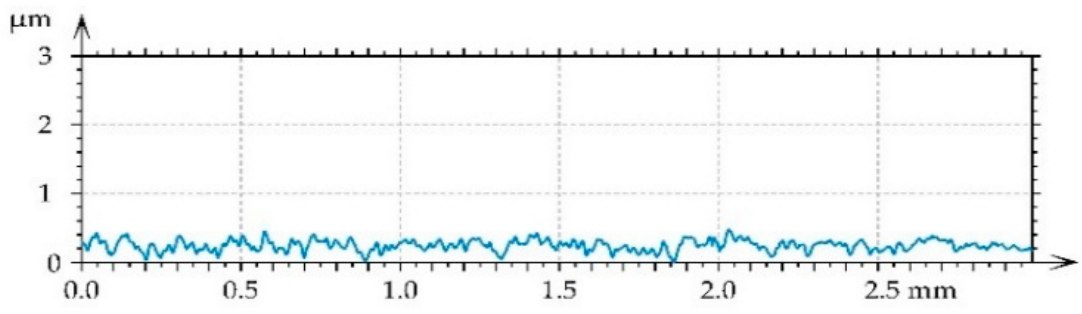

(d)

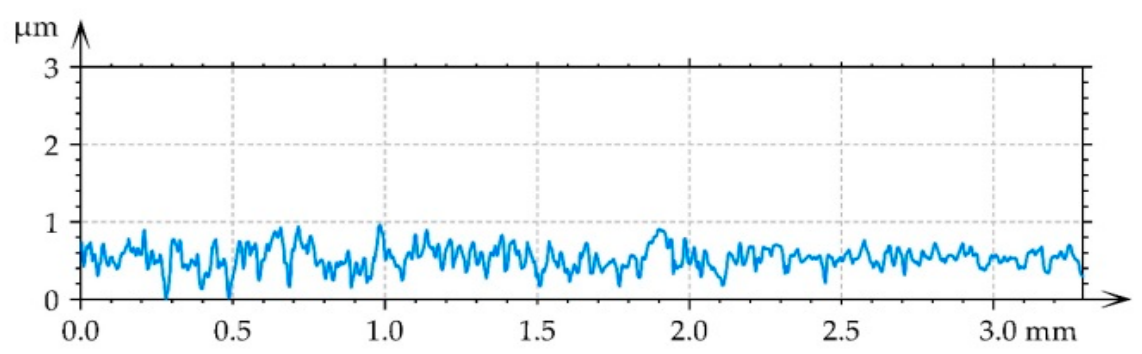

(e)

Figure 3. Representative roughness profiles of milled disc surface (a), and of burnished disc surfaces with pressures of $10(\mathbf{b}), 20(\mathbf{c}), 30(\mathbf{d})$, and $40 \mathrm{MPa}(\mathbf{e})$.

One can see that ball burnishing caused decreases in height parameters: rms. height Sq, average height $S a$, maximum height $S z$, peak height $S p$, valley depth $S v$, and rms. slope Sdq. The decreases were the smallest for the highest pressure of $40 \mathrm{MPa}$. The correlation length Sal increased due to burnishing. The initial milled surface was one-directional anisotropic — the texture parameter Str was very small-0.014. As the results of burnishing 
the isotropy degree increased. The skewness Ssk decreased and kurtosis Sku increased due to burnishing. The values of these parameters confirm that the texture changed from deterministic (milled) to random (burnished). For the highest burnishing pressure surface height was not so small as those obtained for smaller pressures. Perhaps this pressure led to surface deterioration, similar behavior was found in $[5,6]$.

Microhardness values of discs are presented in Figure 4. The five indentations were performed for each disc sample. Due to burnishing, microhardness increased. The growth was the smallest for the lowest burnishing pressure.

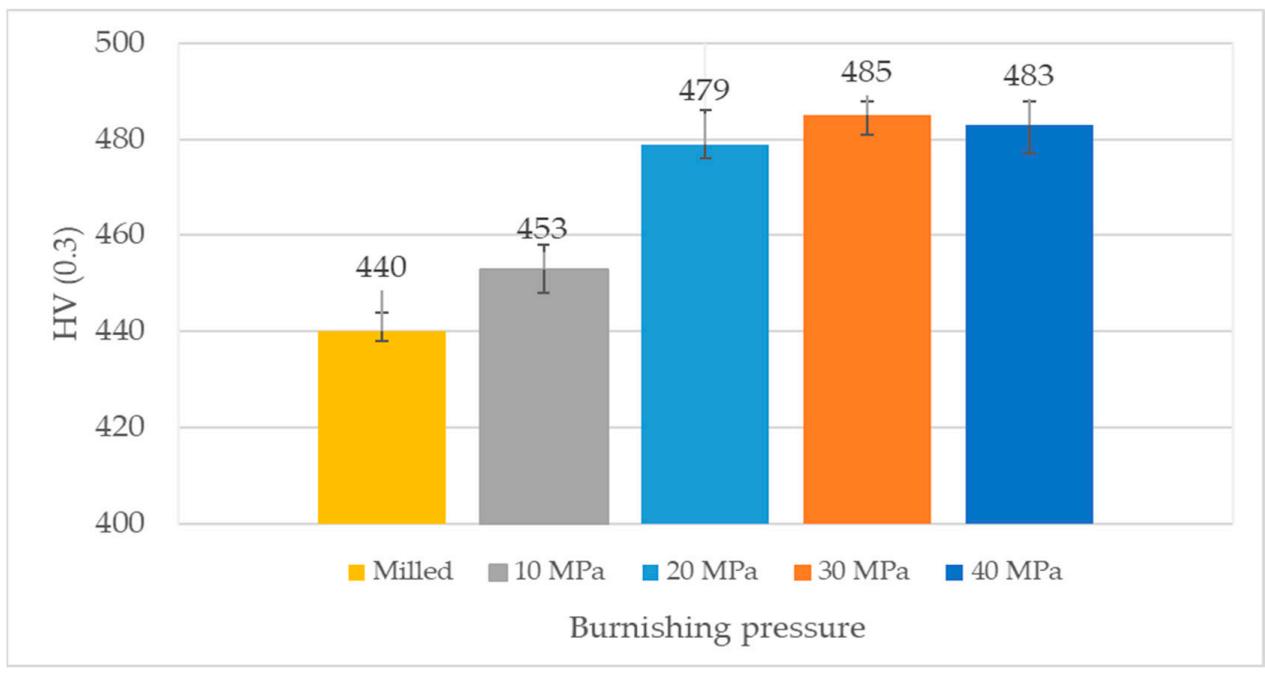

Figure 4. The results of microhardness measurements of discs.

Figure 5 presents runs of the coefficient of friction versus time for various tested assemblies. For the smallest normal loads of 20 and $30 \mathrm{~N}$ the fluctuations of the friction force occurred for the first $200 \mathrm{~s}$, from this time the friction coefficient slowly increased as the test progressed. When the normal load was $40 \mathrm{~N}$, the friction force was stable after about $100 \mathrm{~s}$ and for the normal load of $50 \mathrm{~N}$ after about $50 \mathrm{~s}$. For all applied loads, the highest friction was obtained for assembly with the milled surface, while the smallest was for the burnished surface with the pressure of $30 \mathrm{~N}$.

Figure 6 presents the average values of the coefficient of friction with the scatters after its stabilization (after $240 \mathrm{~s}$ ) and in the final test part (the last $60 \mathrm{~s}$ ). The finishing values of the friction coefficient were higher than the average values. A growth in the normal force caused an increase in the friction coefficient. The scatters of the average coefficients of friction were typically smaller than those of the final friction coefficients. For the smallest load of $20 \mathrm{~N}$, the differences between the average coefficients of friction for assemblies containing burnished samples with pressures of 10, 20, and $40 \mathrm{MPa}$ were negligible. Burnishing pressure of $30 \mathrm{~N}$ caused a decrease in the friction coefficient of $30 \%$. When the normal load was $30 \mathrm{~N}$, ball burnishing with a pressure of $20 \mathrm{MPa}$ led to a smaller friction force in comparison to pressures of $40 \mathrm{MPa}$ and of $10 \mathrm{MPa}$. Under the normal load of $30 \mathrm{~N}$, burnishing with the pressure of $30 \mathrm{MPa}$ caused a reduction in the friction coefficient of about $45 \%$. When normal loads were 40 and $50 \mathrm{~N}$, from among burnished samples the highest coefficients of friction were obtained for the highest burnishing pressure of $40 \mathrm{MPa}$. For the normal loads of 40 and $50 \mathrm{~N}$, ball burnishing led to friction reduction of about $20-25 \%$. For the largest normal load, differences between the average coefficients of friction for discs burnished with pressures of 10, 20, and $30 \mathrm{MPa}$ were negligible. 


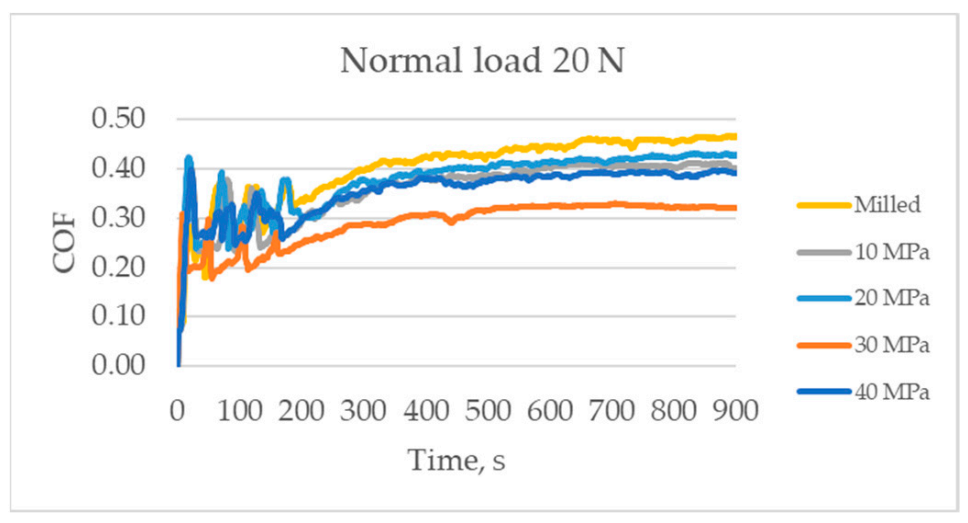

(a)

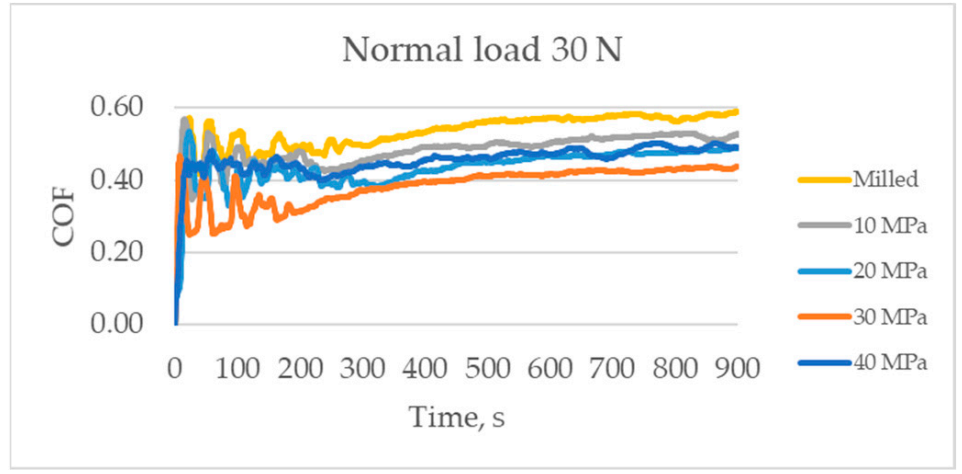

(b)

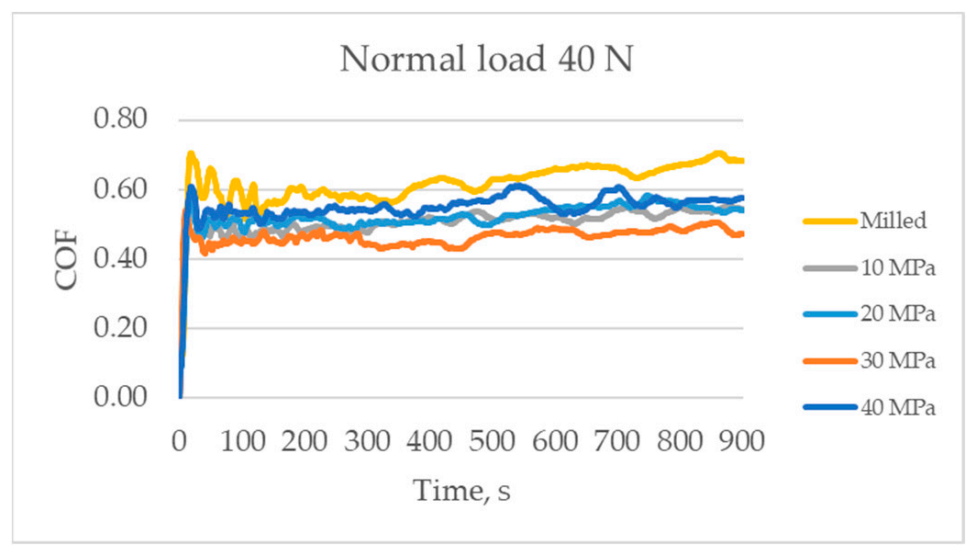

(c)

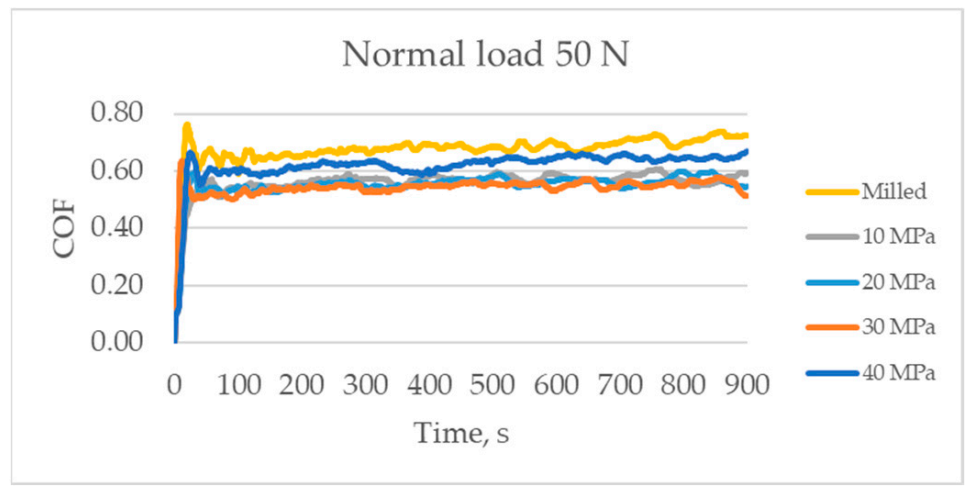

(d)

Figure 5. The friction coefficient as a function of time; the normal load was $20 \mathrm{~N}(\mathbf{a}), 30 \mathrm{~N}(\mathbf{b}), 40 \mathrm{~N}$ (c), and $50 \mathrm{~N}(\mathbf{d})$. 


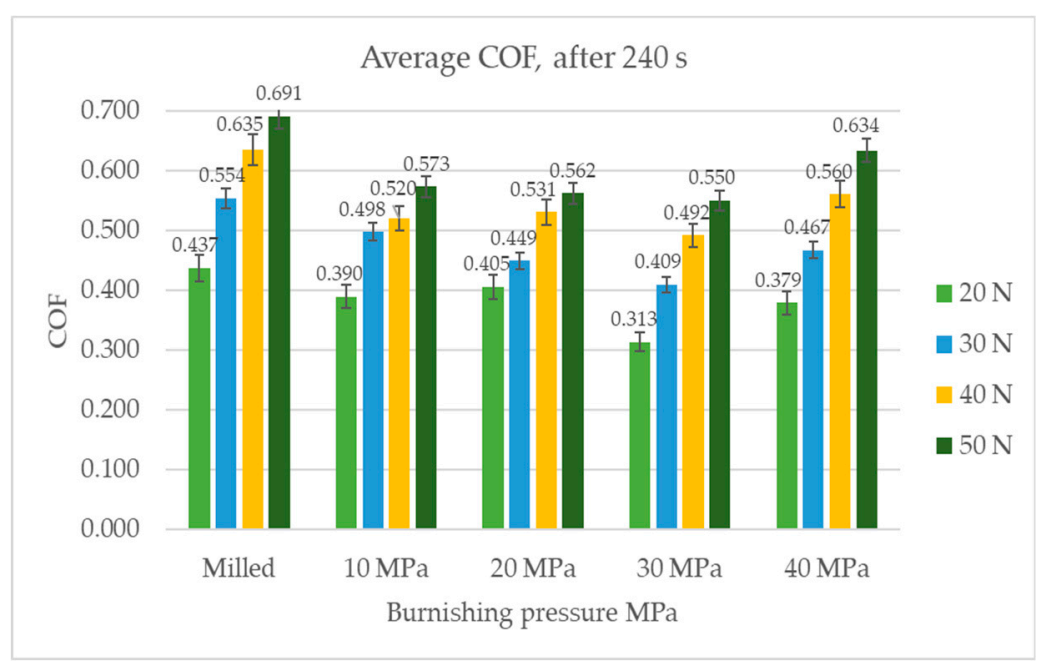

(a)

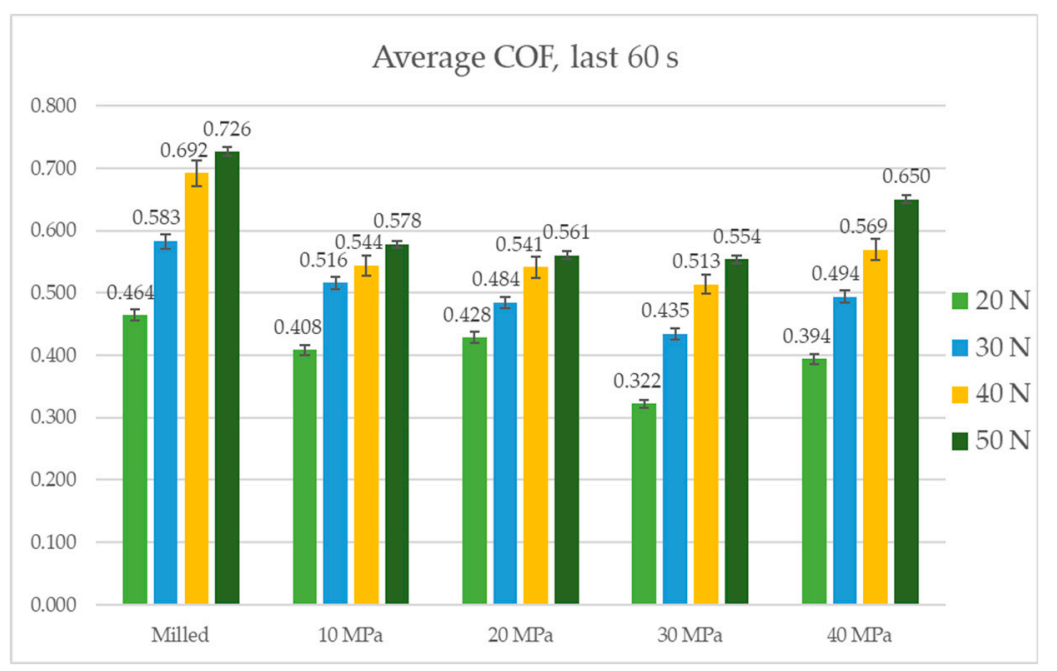

(b)

Figure 6. The average coefficient of friction after $240 \mathrm{~s} \mathrm{(a),} \mathrm{and} \mathrm{for} \mathrm{the} \mathrm{last} 60 \mathrm{~s}$ (b).

Figure 7 presents examples of fretting loops obtained after $10 \mathrm{~min}$ of tests. The shapes of loops are characteristic of gross slip. The values of the slip index $[20,21]$ were between 5 and 7.

Table 2 and Figure 8 present the results of wear examination of elements of the tribological system. Wear levels of discs were higher than those of balls. Typically, the ratio of ball wear to disc wear ranged between 0.2 and 0.3. A growth in the normal load caused a growth in wear volumes of the tribological system. In all analyzed cases ball burnishing led to reduction in wear. For the lowest load, the lowest wear was achieved for burnishing pressures of 20 and $30 \mathrm{MPa}$. The highest reduction of the volumetric wear was $43 \%$. For the normal load of $30 \mathrm{~N}$, the lowest wear was achieved for burnishing pressure of $10 \mathrm{MPa}$, followed by $30 \mathrm{MPa}$, the highest reduction in total volumetric wear due to burnishing was $47 \%$. For the normal load of $40 \mathrm{~N}$, the lowest wear was obtained for the burnishing pressure of $30 \mathrm{MPa}$, followed by 10,20, and $40 \mathrm{MPa}$. The highest reduction in wear volume due to ball burnishing was $47 \%$. When the highest normal load of $50 \mathrm{~N}$ was applied, the lowest volumetric wear of the tribologic system was obtained when the burnishing pressure was $30 \mathrm{MPa}$, followed by 20,40 , and $10 \mathrm{MPa}$-the largest reduction in wear was $40 \%$. Generally, the smallest wear was obtained for the burnishing pressure of $30 \mathrm{MPa}$, when the normal loads were 10,30 , and $40 \mathrm{~N}$. 


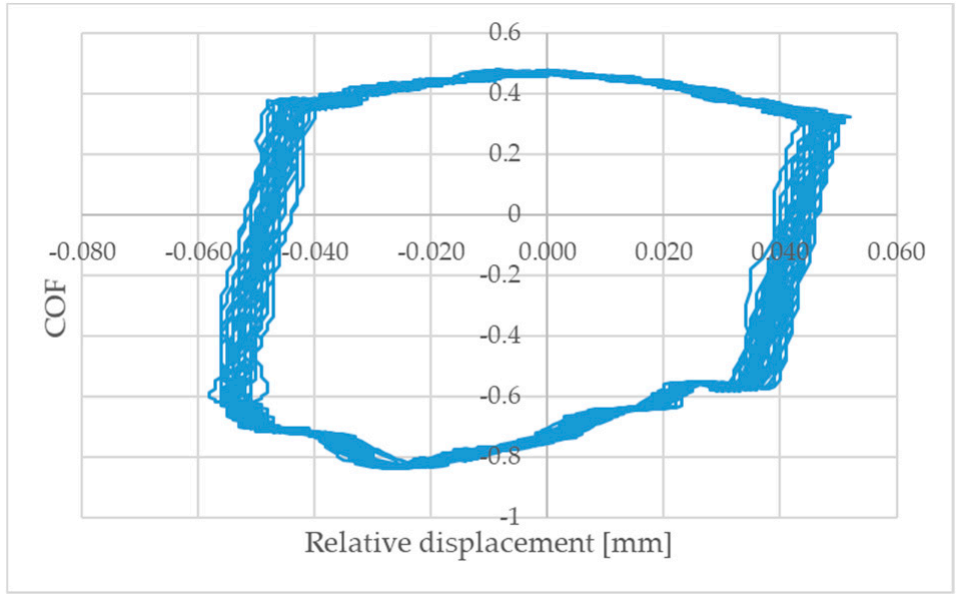

(a)

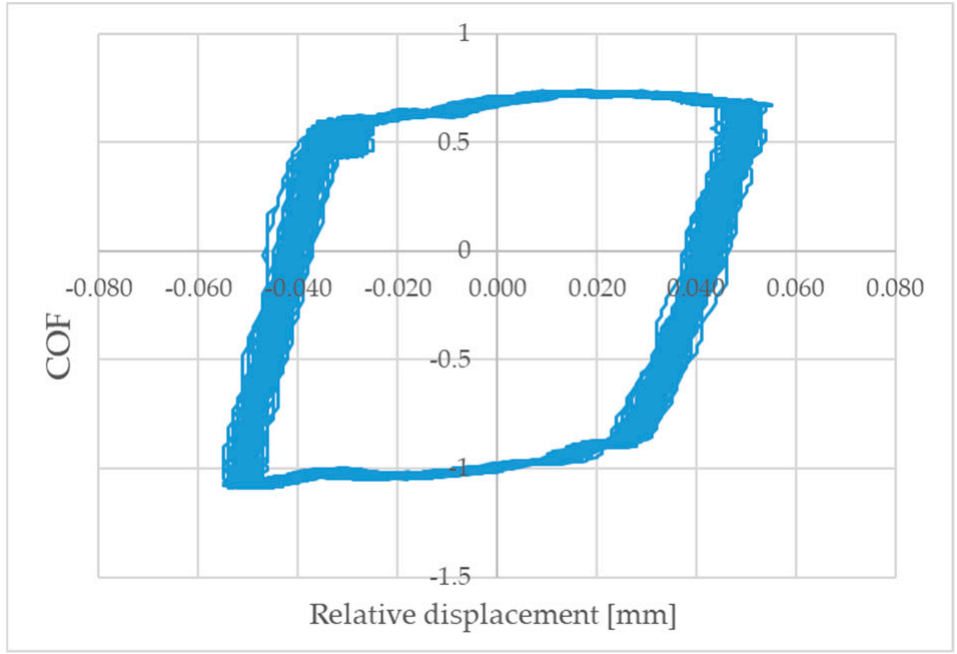

(b)

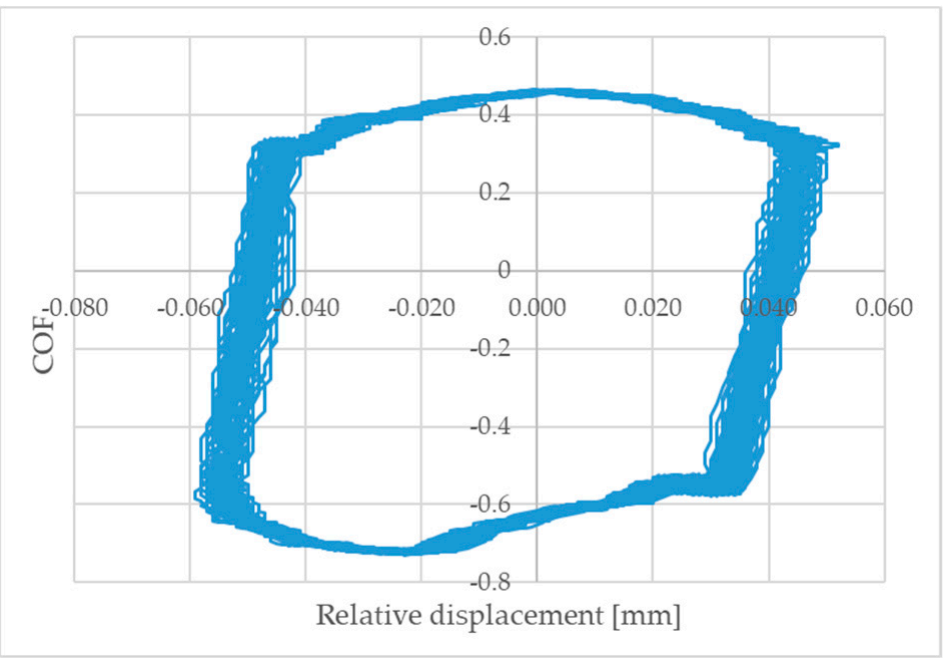

(c)

Figure 7. Fretting loops for sliding pairs with discs: (a) milled-normal force $50 \mathrm{~N}$, (b) burnished-pressure $30 \mathrm{MPa}$ and normal force $20 \mathrm{~N}$, (c) burnished-pressure $30 \mathrm{MPa}$ and normal force $50 \mathrm{~N}$. 
Table 2. The values of volumetric wear of disc $\mathrm{V}_{\text {disc }}$, of balls $\mathrm{V}_{\text {ball, }}$ and of tribological system $\mathrm{V}$.

\begin{tabular}{|c|c|c|c|c|}
\hline $\begin{array}{c}\text { Surface } \\
\text { Preparation }\end{array}$ & Load, $\mathbf{N}$ & $\begin{array}{l}V_{\text {disc, }} \\
\mu \mathrm{m}^{3}\end{array}$ & $\begin{array}{l}\mathrm{V}_{\text {ball, }} \\
\mu \mathrm{m}^{3}\end{array}$ & $\begin{array}{c}V_{,} \\
\mu \mathbf{m}^{3}\end{array}$ \\
\hline \multirow{4}{*}{ Milled } & 20 & 105.396 & 50.140 & 155.536 \\
\hline & 30 & 430.411 & 144.959 & 575.370 \\
\hline & 40 & 849.299 & 200.362 & 1049.661 \\
\hline & 50 & 1263.317 & 275.712 & 1539.029 \\
\hline \multirow{4}{*}{$\begin{array}{l}\text { Burnished, } \\
p=10 \mathrm{MPa}\end{array}$} & 20 & 93.585 & 29.066 & 122.650 \\
\hline & 30 & 210.423 & 86.378 & 296.801 \\
\hline & 40 & 505.780 & 139.739 & 645.518 \\
\hline & 50 & 1001.992 & 240.320 & 1242.312 \\
\hline \multirow{4}{*}{$\begin{array}{l}\text { Burnished, } \\
p=20 \mathrm{MPa}\end{array}$} & 20 & 66.295 & 24.066 & 90.361 \\
\hline & 30 & 307.287 & 85.615 & 392.902 \\
\hline & 40 & 539.396 & 125.088 & 664.483 \\
\hline & 50 & 910.172 & 159.008 & 1069.180 \\
\hline \multirow{4}{*}{$\begin{array}{l}\text { Burnished, } \\
p=30 \mathrm{MPa}\end{array}$} & 20 & 45.116 & 42.675 & 87.791 \\
\hline & 30 & 250.890 & 77.478 & 328.368 \\
\hline & 40 & 493.898 & 69.223 & 563.120 \\
\hline & 50 & 746.124 & 174.991 & 921.114 \\
\hline \multirow{4}{*}{$\begin{array}{l}\text { Burnished, } \\
p=40 \mathrm{MPa}\end{array}$} & 20 & 74.638 & 35.157 & 109.794 \\
\hline & 30 & 302.186 & 59.039 & 361.225 \\
\hline & 40 & 601.640 & 144.338 & 745.977 \\
\hline & 50 & 994.493 & 149.121 & 1143.614 \\
\hline
\end{tabular}

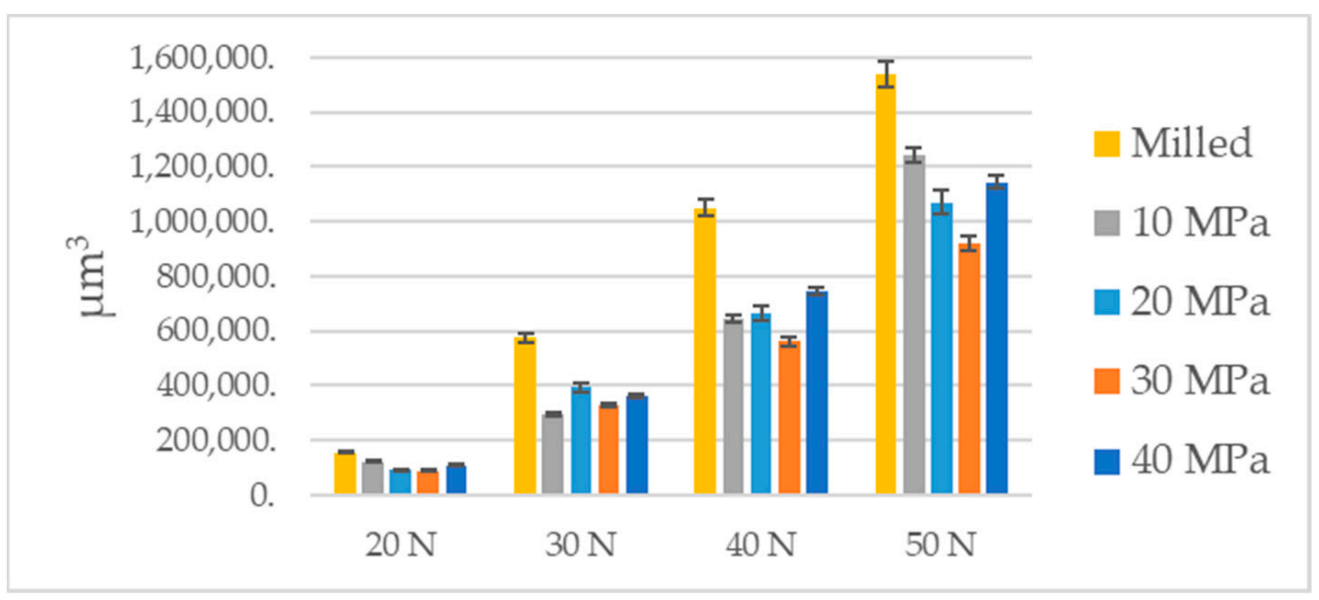

Figure 8. The results of wear examination of disc samples.

Figure 9 shows views and surface profiles containing wear scars for the highest normal load of 50 N. Figure 10 presents selected SEM images of wear scars on disc samples. 

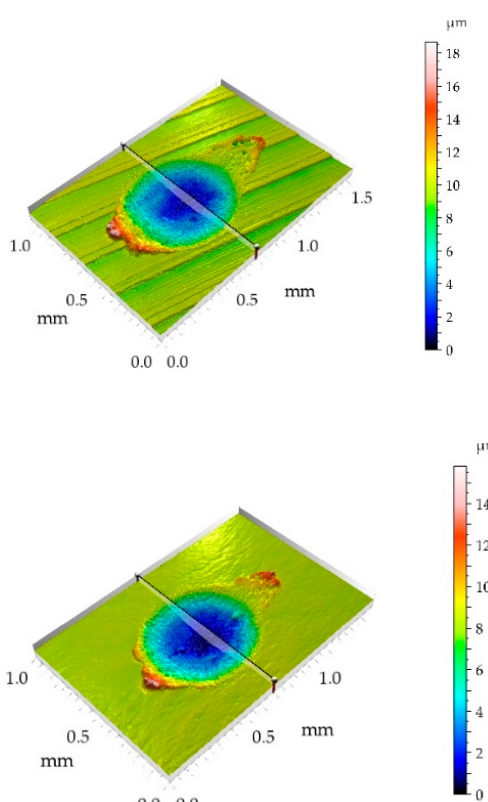

$0.0 \quad 0.0$

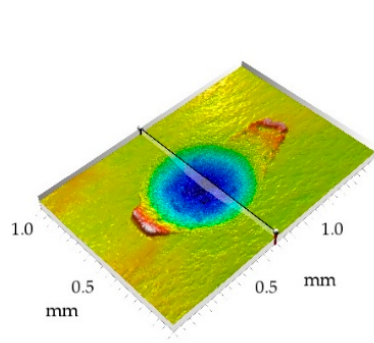

$0.0 \quad 0.0$

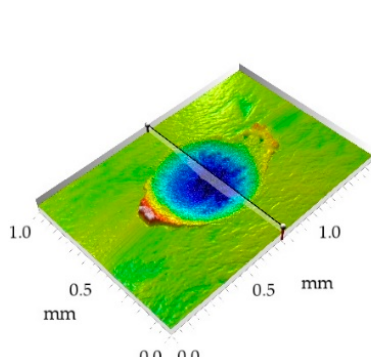

$\begin{array}{lll}0.0 & 0.0\end{array}$

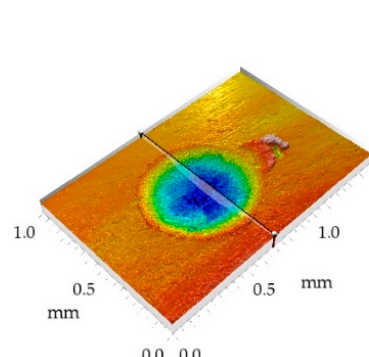

$00-0.0$

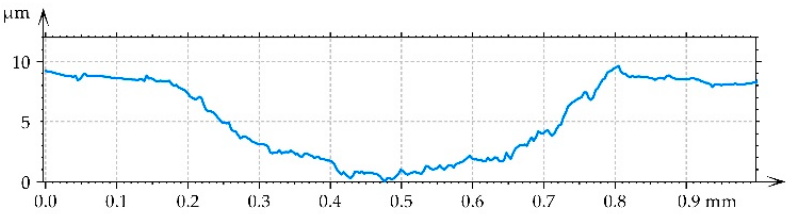

(a)

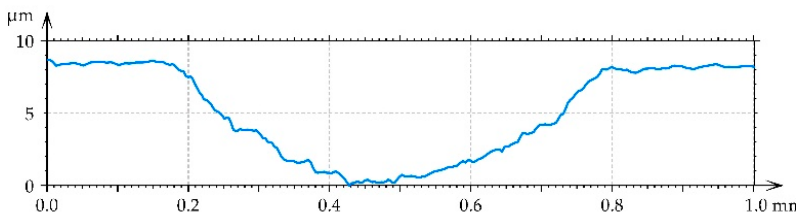

(b)
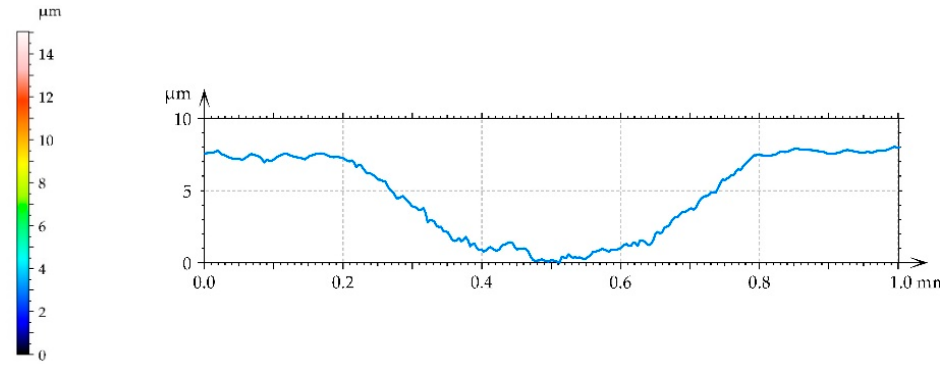

(c)

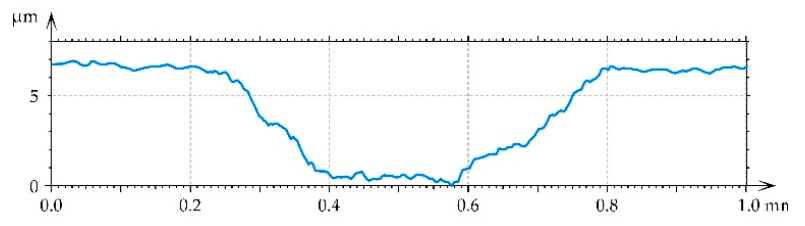

(d)

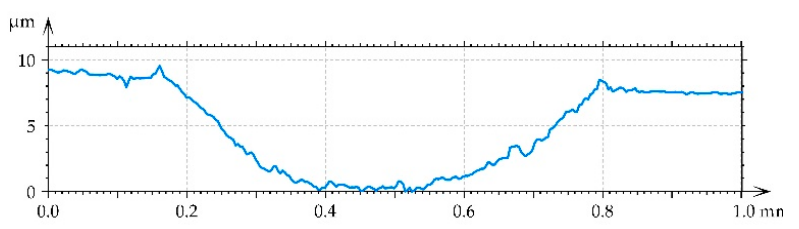

(e)

Figure 9. Isometric views of disc surfaces and profiles orthogonal to wear scars at a normal load of $50 \mathrm{~N}$, (a) milled sample, (b) burnished samples for pressure of $10 \mathrm{MPa}$, (c) $20 \mathrm{MPa}$, (d) $30 \mathrm{MPa}$, (e) $40 \mathrm{MPa}$. 


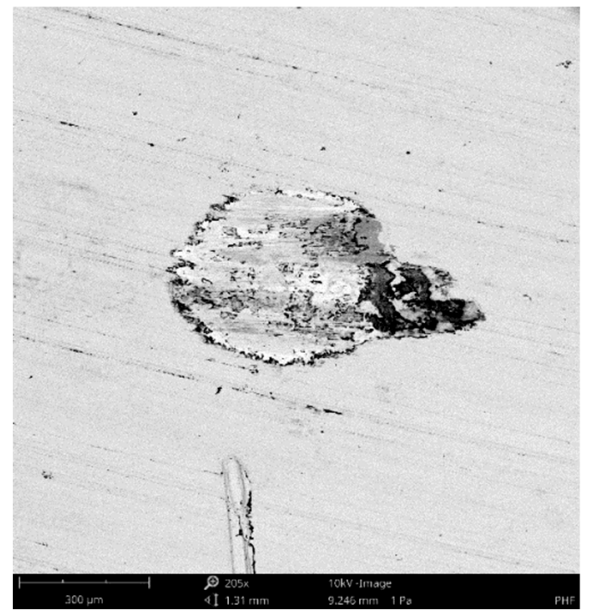

(a)

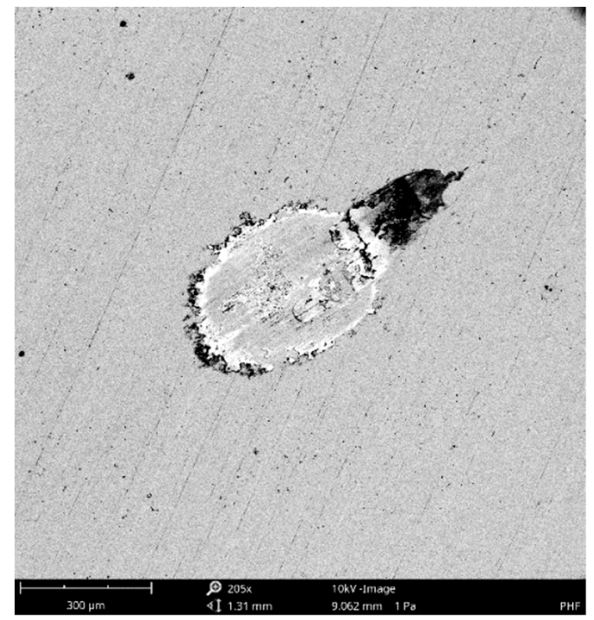

(c)

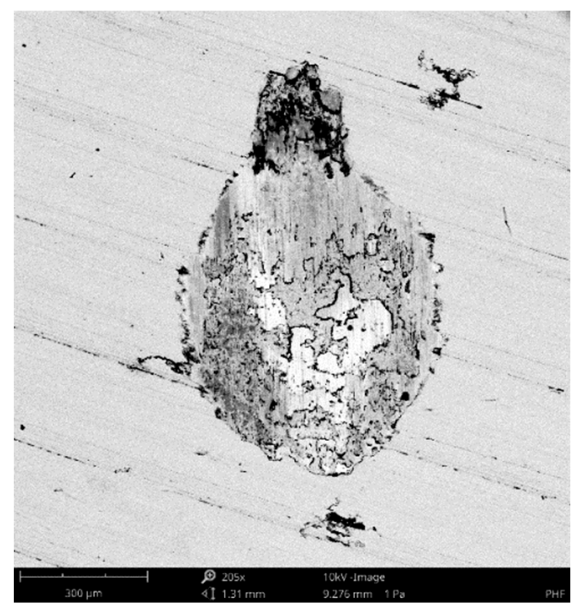

(b)

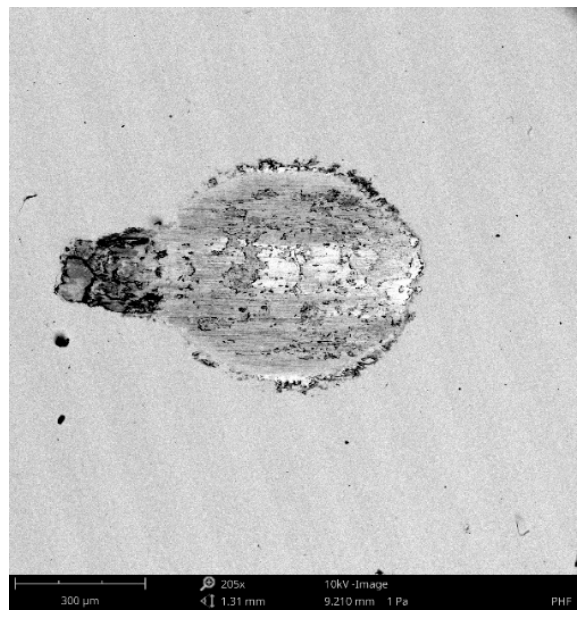

(d)

Figure 10. The SEM views of the milled disc surface after tribological tests for the normal load of $20 \mathrm{~N}$ (a), $40 \mathrm{~N}$ (b), of burnished disc surface with pressure of $10 \mathrm{MPa}$ for the normal load of $20 \mathrm{~N}$ (c) and of burnished disc surface with a pressure of $30 \mathrm{MPa}$ for the normal load of $40 \mathrm{~N}$ (d).

As wear tracks on the disc surfaces had a U shape, abrasion was a dominant type of wear. Plastic deformation of the discs also occurred near the edges of wear scars. Wear was caused by a difference between the values of hardness of two counterparts. As the hardness of the ball was much harder than the hardness of the disc, the wear of the disc was larger than the wear of the ball. Adhesive junctions were not observed, because disc and balls were made of various materials of different hardness.

The smallest coefficients of friction were obtained for ball burnishing with a pressure of $30 \mathrm{MPa}$, the results were substantial for low normal loads of 20 and $30 \mathrm{~N}$. Similarly, ball burnishing with this pressure led to the smallest wear values of the tribologic system for loads of 10, 30, and $40 \mathrm{~N}$. Therefore, for the burnishing pressure of $30 \mathrm{MPa}$, the best performance of tribologic system occurred. This behavior was probably related to the smallest roughness height from all analyzed disc samples. The values of parameters $\mathrm{Sa}, \mathrm{Sq}$, $\mathrm{Sp}, \mathrm{Sz}$ and rms. slope were the smallest. There are two sources of friction: deformation and adhesion of contacted summits. For the contact of ceramic ball with steel disc the adhesion effect was negligible, see Figures 9 and 10. Friction due to deformation of asperities decreased when roughness height decreased. Furthermore, the disc sample obtained with burnishing pressure of $30 \mathrm{MPa}$ was characterized by a negative value of skewness Ssk. The beneficial effects of negative skewness on the tribological performance of sliding elements were previously found under lubricated and dry friction regimes [6,36-38]. In addition, 
ball burnishing caused an increase in microhardness of $10 \%$. From among other samples, the highest frictional resistances were obtained for the highest burnishing pressure of $40 \mathrm{MPa}$, when the highest loads, of 40 and $50 \mathrm{~N}$, were applied. This sample led to the largest volumetric wear of the tribological system for the normal force of $30 \mathrm{~N}$, however, wear levels were also comparatively high when other normal loads were applied. This performance was probably caused by surface texture characterized by comparatively high roughness amplitude and slope (the highest from all burnished discs), for example, the Sq parameter of this sample was about 2.5 times higher than that obtained for the burnishing pressure of $30 \mathrm{MPa}$. In addition, in contrast to other burnished samples, this surface was not homogeneous.

The highest reduction of the friction force and wear volumes due to ball burnishing was near $45 \%$.

The milled sample of the highest roughness, the highest positive skewness and the smallest microhardness produced the highest friction and wear.

An increase in disc roughness height led to an increase in friction and wear of the analyzed tribological system. Similar effects were obtained in [32]. Wear was proportional to friction. The growth in the unitary pressure caused the increase in friction. This performance was caused by the lack of accommodation of surfaces made of various materials in contact. Wear of ball was smaller than wear of disc. This behavior was caused by very high hardness of balls and low affinity between steel and ceramics. The last property caused a lack of formation of adhesive junctions-abrasion was a dominant wear type.

\section{Conclusions}

- Ball burnishing of steel disc in contact with a ceramic ball under dry gross fretting led to reductions in the resistance to motion and volumetric wear up to $45 \%$ in comparison to the milled surface.

- The best tribological performance was achieved for the disc sample created with a burnishing pressure of $30 \mathrm{MPa}$. This disc was characterized by the smallest roughness height and slope and increased microhardness compared to the milled surface.

- The worst tribological behavior was obtained when the burnishing pressure was $40 \mathrm{MPa}$. In this case, the non-homogeneous surface had the highest roughness among the burnished discs.

- Wear levels of discs were smaller than those of balls. The wear had an abrasive character with plastic deformation. The growth in normal load led to the increase in the coefficient of friction. Wear of the tribological system was proportional to friction.

- Ball burnishing led to reductions in roughness height and surface slope and to an increase in microhardness compared to the milled sample. The highest reduction in surface amplitude occurred for burnishing pressure of $30 \mathrm{MPa}$, but the lowestof $40 \mathrm{MPa}$. The lowest microhardness increase occurred for the lowest burnishing pressure of $10 \mathrm{MPa}$.

Author Contributions: Conceptualization: P.P., S.S.; methodology, investigation, and formal analysis: S.S.; writing—original draft preparation: P.P., S.S.; writing—review and editing: P.P., S.S. All authors have read and agreed to the published version of the manuscript.

Funding: This research received no external funding.

Institutional Review Board Statement: Not applicable.

Informed Consent Statement: Not applicable.

Data Availability Statement: The data presented in this study are available on request from the corresponding author.

Conflicts of Interest: The authors declare no conflict of interest. 


\section{References}

1. Maheshwari, A.S.; Gawande, R.R. The Role of Burnishing Process in Manufacturing Industry. Int. J. Eng. Res. Dev. 2017, 13, 50-60.

2. Saldaña-Robles, A.; Plascencia-Mora, H.; Aguilera-Gómez, E.; Saldaña-Robles, A.; Marquez-Herrera, A.; Diosdado-De La Peña, J.A. Influence of Ball-Burnishing on Roughness, Hardness and Corrosion Resistance of AISI 1045 Steel. Surf. Coat. Technol. 2018, 339, 191-198. [CrossRef]

3. Jerez-Mesa, R.; Travieso-Rodríguez, J.A.; Landon, Y.; Dessein, G.; Lluma-Fuentes, J.; Wagner, V. Comprehensive Analysis of Surface Integrity Modification of Ball-end Milled Yi-6Al-4V Surfaces Through Vibration-Assisted Ball Burnishing. J. Mater. Process. Technol. 2019, 267, 230-240. [CrossRef]

4. El-Tayeb, N.S.M.; Low, K.O.; Brevern, P.V. Enhancement of Surface Quality and Tribological Properties Using Ball Burnishing Process. Mach. Sci. Technol. 2015, 12, 234-248. [CrossRef]

5. Rodríguez, A.; de Lacalle, L.N.L.; Celaya, A.; Lamikiz, A.; Albizuri, J. Surface Improvement of Shafts by the Deep Ball-Burnishing Technique. Steel. Surf. Coat. Technol. 2012, 206, 2817-2824. [CrossRef]

6. Swirad, S.; Pawlus, P. The Effect of Ball Burnishing on Tribological Performance of 42CrMo4 Steel Under Dry Sliding Condition. Materials 2020, 13, 2127. [CrossRef]

7. Buldum, B.; Cagan, S. Study of Ball Burnishing Process on the Surface Roughness and Microhardness of AZ91D Alloy. Exp. Tech. 2018, 42, 233-241. [CrossRef]

8. Cobanoglu, T.; Ozturk, S. Effect of Burnishing Parameters on the Surface Quality and Hardness. Proc. Inst. Mech. Eng. B J. Eng. Manuf. 2015, 229, 286-294. [CrossRef]

9. Hiegemann, L.; Weddeling, C.; Khalifa, B.N.; Tekkaya, A.E. Prediction of Roughness After Ball Burnishing of Thermally Coated Surfaces. J. Mater. Process. Technol. 2015, 217, 193-201. [CrossRef]

10. Hiegemann, L.; Weddeling, C.; Tekkaya, A.E. Analytical Contact Pressure Model for Predicting Roughness of Ball Burnished Surfaces. J. Mater. Process. Technol. 2016, 232, 63-77. [CrossRef]

11. Revankar, G.; Raviraj, S.; Shrikantha, S.; Vinayak, N. Wear Resistance Enhancement of Titanium Alloy (Ti-6Al-4V) by Ball Burnishing Process. J. Mater. Res. Technol. 2017, 6, 13-32. [CrossRef]

12. Travieso-Rodríguez, J.; Jerez-Mesa, R.; Gómez-Gras, G.; Llumà-Fuentes, J.; Casadesús-Farràs, O.; Madueño-Guerrero, M. Hardening Effect and Fatigue Behavior Enhancement Through Ball Burnishing on AISI 1038. J. Mater. Res. Technol. 2019, 8 , 5639-5646. [CrossRef]

13. Mitrovic, S.; Adamovic, D.; Zivic, F.; Dzunic, D.; Pantic, M. Friction and Wear Behavior of Shot Peened Surfaces of 36CrNiMo4 and 36NiCrMo16 Alloyed Steels Under Dry and Lubricated Contact Conditions. Appl. Surf. Sci. 2014, 290, 223-232. [CrossRef]

14. Han, X.; Zhang, Z.; Hou, J.; Barber, G.C.; Qiu, F. Tribological Behavior of Shot Peened/Austempered AISI 5160 Steel. Tribol. Int. 2020, 145, 106197. [CrossRef]

15. Swirad, S.; Pawlus, P. The Influence of Ball Burnishing on Friction in Lubricated Sliding. Materials 2020, 13, 5027. [CrossRef] [PubMed]

16. Fouvry, S.; Kapsa, P.; Vincent, L. Analysis of Sliding Behavior for Fretting Loading: Determination of Transition Criteria. Wear 1995, 185, 21-46. [CrossRef]

17. Vingsbo, O.; Soerberg, S. On Fretting Maps. Wear 1988, 126, 131-147. [CrossRef]

18. Zhou, Z.R.; Nakazawa, S.; Zhu, M.H.; Maruyama, N.; Kapsa, P.; Vincent, L. Progress in Fretting Maps. Tribol. Int. 2006, 39, 1068-1073. [CrossRef]

19. Varenberg, M. Towards a Unified Classification of Wear. Friction 2013, 1, 333-340. [CrossRef]

20. Varenberg, M.; Etsion, I.; Halperin, G. Slip Index: A New Unified Approach to Fretting. Tribol. Lett. 2004, 17, 569-573. [CrossRef]

21. Varenberg, M.; Etsion, I.; Altus, E. Theoretical Substantiation of the Slip Index Approach to Fretting. Tribol. Lett. 2005, 19, 263-264. [CrossRef]

22. Varenberg, M.; Halperin, G.; Etsion, I. Different Aspects of the Role of Wear Debris in Fretting Wear. Wear 2002, 252, 902-910. [CrossRef]

23. Iwabuchi, A. The Role of Oxide Particles in the Fretting Wear of Mild Steel. Wear 1991, 151, 337-344. [CrossRef]

24. Raeymaekers, B.; Talke, F.E. The Effect of Laser Polishing on Fretting Wear Between a Hemisphere and a Flat Plate. Wear 2010, 269, 416-423. [CrossRef]

25. Kayanba, T.; Iwabuchi, A. Effect of Hardness of Hardened Steel and the Action of Oxides on Fretting Wear. Wear 1981, 66, 27-41. [CrossRef]

26. Budinsky, K.C. Effect of Hardness Differential on Metal-to-Metal Fretting Damage. Wear 2013, 301, 501-507. [CrossRef]

27. Fu, Y.; Wei, J.; Batchelor, A.W. Some Considerations on the Mitigation of Fretting Damage by the Application of SurfaceModification Technologies. J. Mater. Process. Technol. 2000, 99, 231-245. [CrossRef]

28. Kubiak, K.J.; Mathia, T.G.; Fouvry, S. Interface Roughness Effect on Friction Map Under Fretting Contact Conditions. Tribol. Int. 2010, 43, 1500-1507. [CrossRef]

29. Kubiak, K.J.; Mathia, T.G. Influence of Roughness on Contact Interface in Fretting Under Dry or Lubricated Sliding Regimes. Wear 2009, 267, 315-321. [CrossRef]

30. Lenart, A.; Pawlus, P.; Dzierwa, A. The Effect of Disc Surface Topography on the Dry Gross Fretting Wear of an Equal-Hardness Steel Pair. Materials 2019, 12, 3250. [CrossRef] 
31. Lenart, A.; Pawlus, P.; Dzierwa, A.; Sep, J.; Dudek, K. The Effect of Surface Topography on Dry Fretting on the Gross Slip Regime. Arch. Civ. Mech. Eng. 2017, 17, 894-904. [CrossRef]

32. Lenart, A.; Pawlus, P.; Dzierwa, A. The Effect of Steel Disc Surface Texture in Contact With Ceramic Ball on Friction and Wear in Dry Fretting. Surf. Topogr. 2018, 6, 034004. [CrossRef]

33. Lu, W.; Zhang, P.; Liu, X.; Zhai, W.; Zhou, M.; Luo, J.; Zeng, W.; Jiang, X. Influence of Surface Topography on Torsional Fretting Wear Under Flat-on-Flat Contact. Tribol. Int. 2017, 109, 367-372. [CrossRef]

34. Berthier, Y.; Vincent, L.; Godet, M. Fretting Fatigue and Fretting Wear. Tribol. Int. 1989, 22, 235-242. [CrossRef]

35. Pawlus, P.; Reizer, R.; Wieczorowski, M. Functional Importance of Surface Texture Parameters. Materials 2021, 14, 5326. [CrossRef] [PubMed]

36. Dzierwa, A. Influence of surface preparation on surface topography and tribological behaviours. Arch. Civ. Mech. Eng. 2017, 17, 502-510. [CrossRef]

37. Dzierwa, A.; Pawlus, P.; Zelasko, W. The influence of disc surface topography after vapour blasting on friction and wear of sliding pairs under dry friction conditions. Coatings 2020, 10, 102. [CrossRef]

38. Sedlacek, M.; Podgornik, B.; Vizintin, J. Correlation between standard roughness parameters skewness and kurtosis and tribological behaviour of contact surfaces. Tribol. Int. 2012, 48, 102-112. [CrossRef] 